\title{
The Ascending Trend of Environmental Marketing in the Current Austerity/Crisis Period
}

\author{
Ilie Budică $\breve{1}^{1}$ Aurelia Dumitru-Traistaru ${ }^{2 *}$ \\ 'University of Craiova, 13 A. I. Cuza Street, code 200585, Craiova, Romania \\ 2“"Matei Basarab" High School, 113 V. Alecsandri Street, code 200463, Craiova, Romania
}

Received: March 31, 2015

Accepted: April 20, 2015

\begin{abstract}
This study concerns the distinctive specialty of environmental marketing. The starting point for our research is a consideration of the effects of crisis on environmental marketing activities.

Using observation, direct analysis, and meta-analysis as methods, this study attempts to clarify behavior modifications in the current period of austerity. Specifically, the study examines the impact of the financial crisis on environmental marketing.

A primary assertion is that the environmental/green concept has become a moral value and an actual mode of social behavior. People (suppliers, buyers, customers, and stakeholders) have an affinity for the "environmental-green" (as above) concept. These people exhibit a favorable attitude toward green issues; they progress from sensitivity through to awareness and responsibility. The second assertion is that costs exist in relation to the "environmental-green" concept; however, from the start of the global financial crisis, despite falling living standards, people did not suppress their "environmental-green" behavior. In addition to the "environmental-green" concept, the principal tool of consent conservation was created by green marketing management.

The conclusion is that, in an actual period of austerity, environmental marketing maintained the growing trend attached to the "environmental-green" concept.
\end{abstract}

Keywords: environmental/green marketing, environmental consumer, environmental-green place, environmental products, environmental production, environmental promotion, environmental packing

\section{Introduction}

Environmental marketing was developed as a study domain within the broader field of marketing. Kotler defines the domain as a "set of human activities directed at facilitating and consummating exchanges." He considers that "a marketing situation" is identified through three elements:

a) Parties: "two or more parties who are potentially interested in exchange"

b) Possessions: "each possessing things of value to the other"

*e-mail: aurelia.dumitru.traistaru@gmail.com c) Capacity for communicational and material transaction: "each capable of communication and delivery" [1].

We approach marketing with the understanding that it is a practical activity. The discipline at the forefront of these practical activities, marketing, is "the science and art of exploring, creating, and delivering value to satisfy the needs of a target market at a profit. Marketing identifies unfulfilled needs and desires. It defines, measures and quantifies the size of the identified market and the profit potential. It pinpoints which segments the company is capable of serving best and it designs and promotes the appropriate products and services" [2]. Drucker [3] configures "the marketing view of business." $\mathrm{He}$ asserts that 
"Marketing is not a function of business, but a view of the entire business seen as the economic organ to provide goods and services. (...) Everything the business does in that respect is marketing." Marketing is not solely concerned with sales, but "it encompasses the whole business concern" and is constituted as "a process which converts a source, distinct knowledge into a contribution of economic value in the marketplace. The purpose of the business is to create a customer." Furthermore, in 2012 Drucker added what was called "Drucker's Maxim": "The purpose of the business is to create a customer and to satisfy a customer" [4].

Practical operation-specific marketing would be:

a) Decoding and identifying the "unfulfilled needs and desires" of a target market

b) Predicting certain products' necessity

c) Product development that satisfies "needs and desires"

d) Once products satisfy needs, these will retain old customers and attract new ones

e) Customer fidelization (loyalty business model)

As observed, marketing forecasts the sale. A product is sold after it exists; after we have the product we put it on sale. Marketing starts not only before the sale but also before a product's existence. Additionally, marketing does not end with the sale. Marketing activities are interconnected. Marketing surrounds the sell-buy processes. Beyond trade, marketing is customer therapy: it diagnoses the customer's needs and satisfies these by creating the product [5].

Environmental marketing has strong associations with metaphor, which are both critical and practical for Ecological/Green Marketing. Human beings are, by nature, sensitive to symbolism. Environmental Marketing is proof that in many cases, when there is a choice between synonymic variants, people prefer those with a symbolic connotation. The marketing scientific community and outsiders prefer the term environmental marketing. Activities belonging to environmental marketing are principally a strategic marketing management issue. Decision-making stuff determines whether to develop an "environmental-green" marketing component.

The idea of a specialty within the marketing discipline that focuses on environmentally/ecologically safe products first appeared in the 1980s. The moniker ecological marketing was imposed at the end of the 1980s and beginning of the 1990s. The first volume of "ecological marketing" appeared in 1976 and contains the works of a 1975 workshop on this subject; the workshop was organized by the American Marketing Association (AMA). At that event, Henion and Kinnear [6] defined ecological marketing as an object having "positive and negative aspects of marketing activities on pollution, energy depletion and non-energy resource depletion." In 2010, Murthy found that the specifics of "green marketing" consist of marketing activities that satisfy "human needs and wants," with "minimal detrimental impact on the natural environment" [7]. In the configuring of green marketing, later contributions by Peattie [8], Ottman [9], Coddingon [10], and Polonsky [11] played important roles.

\section{Four Significant Transformations}

Since drafting the idea in the 1980s, the environmental/ecological/green marketing project has performed five evolutions and significant transformations

a) Firstly, the title, environmental/ecological/green marketing, was not a stable one. Stead and Stead [12] discussed "environmental marketing." In 2011, Turcuţ discussed "ecological marketing" [13]. In a defining analysis of green marketing, Turcut concludes "the literature does not provide a conjugation of views towards a unanimous opinion on green marketing."

b) With this lack of certainty regarding title, green marketing was imposed as a specialty with a specific profile created according to basic marketing discipline. Greenenvironmental marketing "is gaining popularity" [14].

c) The third significant transformation is object extension. From environmental marketing's initial focus on green products (and services) alone [15], environmental marketing theory expanded to consider green characteristics at the center of all "marketing mix" components. Windsor observes that we associate with "managing and reducing the environmental impact of products and services" [14]; in addition, he observed that "During the 1990 s, the concept of environmental marketing emerged, referring to activities that put product and stewardship at the center of an organization's marketing efforts" [12]. At the same time, 10-20 years ago, while aligning with "environmental-green" concerns, product marketing also considered consumers. Coddington discussed "quasi-green products," "green consumers," and "green consumerism" [10]. The single initial objective thus became "two objectives: to develop environmentally friendly (green) products (...); and to project an image to consumers that these products are both high quality and environmentally sensitive" [12]. In addition to these objectives noted by the three cited authors, in our opinion, five contemporary challenges further emphasized and focused attention on environmental marketing. Pride and Ferrell asserted another object extension: "Green Marketing is a strategic process involving stakeholder assessment to create meaningful long-term relationships with customers while maintaining, supporting, and enhancing the natural environment" [16].

In our belief, the "environmental" objectives of environmental marketing must all be components of the "marketing mix": environmental product, environmental production, environmental place, environmental promotion, environmental packing, and physical environment.

d) The fourth transformation is based on the idea that environmental marketing has become a social responsibility issue and must be promoted. An environmental marketing culture is necessary. Means and methods to promote "greener behaviors" must be identified. Consumers must be better informed with regard to the following:

- Environmental issues generated by consumed products

- Features, qualities, and benefits of environmentalgreen products 
- Producers' efforts through environmental technologies and procedures to create green-environmental products

Communication has an essential role. Jannuzzi was director of product stewardship at a division of Johnson \& Johnson. In a book about "Greener Products," the former director emphasized: "Green marketing is all about communication. The greenest product in the world is useless if no one knows it's available" [17]. Fuller considers the possibility of a green-environmental standard. Fuller characterizes environmental marketing as "sustainable marketing" and defines it as a process that must respect "criteria": "the process of planning, implementing, and controlling the development, pricing, promotion, and distribution of products in a manner that satisfies the three following criteria:

(1) customer needs are met

(2) organizational goals are attained

(3) the processes are compatible with ecosystems" [18].

\section{The Influence of the Financial Crisis}

There are many indicators of the global economic crisis. Principal among these are salary reductions, decreased profits, macro-disequilibrium, and global microeconomic decline. There are also the factors of credit appreciation, decrease in investments, inhibited consumption, a diminished new product promotion rate in the market, circumspection to engage new borrowers, and a reduction in transactional products in the market. This creates confusion, suspicion, angst, and fear among the population, a heightened sense of emergency, and insecurity related to market evolution and world activities. The crisis had a very rapid negative effect on the following: buyer population, producers, products, prices, new product needs, promotion, production processes and sales, and product positioning in the market $[19,20]$. The negotiation power of suppliers and transactional power of customers also were affected. Competitive market rivalry was emphasized. With this background, fake products appeared, accessed through market surrogates and substitutes; accordingly, there were decreases in the quality of material products and in the service sector. If we closely examine factors affected by the crisis, we ascertain that the majority are generic objects of marketing $[21,22]$. The crisis focused on the critical objects of marketing. We consider objects and the epistemic-praxeology objects of marketing those elements that compound "marketing mix" and marketing forces.

In marketing, two sets of "Ps" were discussed. Firstly, in the 1960s Edmund Jerome McCarthy [23] asserted that marketing activities are distributed in four zones, referred to as the "4Ps": product, pricing, place, and promotion. Borden ascertained that this configuration of four "marketing activities" forms a unit that he called a "marketing mix" [24]. Watershoot and Bulte consider that "The concept of the marketing mix is one of the basic ideas of marketing" [25]. To those 4Ps, another 5Ps were added: people, process, physical environment, packing, and positioning [26].
Porter developed the so-called "five forces analysis." Through this analysis, Porter defines a company's functions. If marketing mix moves activities to the fore, Porter emphasizes the forces that inspire the activities. Porter shows that these can be explained as the threats, pressures, and interventions of five strategic forces: the bargaining power of suppliers, the bargaining power of customers, the threat of substitute products or services, the threat of established rivals (the intensity of competitive rivalry) and the threat of new entrants [27]. However, in substantiating the "5Fs", Porter also helps to consolidate "P" lines; he validates "positioning" as a strategic element [28].

It was noticed that under conditions of austerity social systems and eco-systems tend to lose financial balance and, at the same time, subjectivity accentuates the influence of emotional arguments over rational ones. Additionally, the researchers concluded that negotiation in markets suffers from a persuasive distortion, amplifying emotion-based decisions. The market has "great expectations." The "environmental" phenomenon - and environmental marketing in particular - is supported by rational decisions and is established by major social responsibilities to ameliorate the damage to the planetary environment and cease degrading behaviors. Marketing is primordial and principally focuses on profit. Environmental marketing is derived and principled and therefore has associated costs. The costs are supported by a rational decision. In crisis conditions, marketing profits decrease and emotional arguments (based on fear of bankruptcy or on fear of sales reductions) undermine the rational argument of environmental marketing behavior. Under crisis pressure, the expenses that are cut first are those that reduce profit. According to this logic, the expense of environmental marketing appears among those at risk of cancellation. Surprisingly, although the financial logic predicts the cancellation of environmental marketing activities, the environmental market has been conserved and is consolidating. The explanation for this is that the environmental market, although a financial item, is valuable because of its moral responsibility. Symbolically, people understand that one must be responsible for the ship on which one lives. Consumers understand that the environment in which we live has no goal related to us, but we have goals related to it. The first goal is ecological, an "environmental" goal. Thus, maintaining an "environmental" planet Earth became both a personal responsibility and a strategic management decision. To ensure that environmental marketing is not pointless or senseless, it is and will be conserved through marketing management. "Environmental" has entered the lives of responsible people concerned with the planet, but has also entered reasonable and responsible strategic marketing management decisions. Environmental behavior and environmental marketing are viewed today as a standard for responsible people [29]. This is the same as honesty, justice or truth; "environmental-green" originated from a strictly mercantile logic and was consolidated as an axiological standard of human responsibility and as corporate social responsibility. Corporate social responsibility has many positive effects, both in the wider community and in the socioeconomic field of the actor engaged in those activities. 


\section{Conclusions}

Thirty years after the advent of environmental marketing and after 20 years of segregation from the base discipline (marketing), environmental marketing has undergone four critical transformations:

i) Validating the title (changing from green marketing and ecological marketing to environmental marketing)

ii) Being clearly defined as autonomous in relation to the paradigmatic discipline of marketing

iii) Extending the epistemic-praxeology object (from an initial concern for environmental products to concern regarding the 9Ps, beginning as an environmental marketing mix, then undergoing progressive amplification from the 4Ps to the 9Ps)

iv) Becoming a standard of social responsibility, with "environmental" an important value of the human condition; consolidated as such, environmental marketing resisted the 9-10 year austerity period (2006-15)

Most importantly, environmental marketing has remained in the ascendant, defying the financial logic of drastic reductions in allocated funds to reduce costs. The explanation for the maintenance of the positive trend consists of the idea of "environmental-green" being installed as an axiological standard of human responsibility for planet Earth.

\section{References}

1. KOTLER P. Marketing Management: Analysis Planning and Control. ( $2^{\text {nd }}$ ed.). Englewood Cliffs, NJ: Prentice-Hall, 1972.

2. KOTLER P. Marketing Management. (14 ${ }^{\text {th }}$ ed). Harlow: Pearson Education, 2011.

3. DRUCKER P.F. The Practice of Management. New York, Harper \& Row, 1954.

4. DRUCKER P.F. Management. Routledge, 2012.

5. GUMUŁA S., PYTEL K., PIASKOWSKA-SILARSKA M. Environmental and Economic Benefits of Using Kinetic Wind Energy to Generate Electricity. Pol. J. Environ. Stud., 23, (6), 2315, 2014.

6. HENION K.E., KINNEAR T.C. A guide to ecological marketing. Ecological Marketing. Columbus, Ohio: American Marketing Association, 1976.

7. MURTHY P. S. R. Strategic green marketing for survival. Electronic copy available at SSRN: http://dx. doi. org/10.2139/ssrn, 1650560, 2010.

8. PEATTIE K. Green Marketing. London: Pitman Publishing, 1992.
9. OTTMAN J.A. Green marketing. NTC Business Books, 1993.

10. CODDINGTON W. Environmental marketing: positive strategies for reaching the green consumer. McGraw-Hill Companies, 1993.

11. POLONSKY M. An Introduction to Green Marketing, Electronic Green Journal, 1, 33, 1994.

12. STEAD J.G., STEAD W.E. Sustainable strategic management: an evolutionary perspective. International Journal of Sustainable Strategic Management, 1, (1), 62, 2008.

13. TURCUT N.O. The ecologic marketing. Analele Universităţii din Oradea, Fascicula: Protecția Mediului, 17, 896, 2011.

14. WINDSOR S.E. An introduction to green process management. ASQ Quality Press, 2010.

15. KRZYSZTOFIK R., RUNGE J., KANTOR-PIETRAGA I. Paths of environmental and economic reclamation: the case of post-mining brownfields. Pol. J. Environ. Stud., 21, (1), 219, 2012.

16. PRIDE W.M., FERRELL O.C. Marketing foundations. South-Western Cengage Learning, 2011.

17. JANNUZZI Al. Greener products: The making and marketing of sustainable brands. CRC Press, 2011.

18. FULLER D.A. Sustainable marketing: Managerial-ecological issues. Sage Publications, 1999.

19. VOINEA D.V., BUSUU O.V., OPRAN E.R., VLĂDUȚESCU Ș. Embarrassments in Managerial Communication. Polish Journal of Management Studies, 11, (2), 171, 2015.

20. HEŁDAK M, RASZKA B. Evaluation of the spatial policy of a commune with regard to planned land use. Pol. J. Environ. Stud., 22, (1), 395, 2013.

21. NEGREA X., TEODORESCU B. Social-Political Communication Infusing Societal Environment. ProcediaSocial and Behavioral Sciences, 2015.

22. SMARANDACHE F., VLĂDUȚESCU Ș. Towards a Practical Communication Intervention. Revista de cercetare şi intervenţie socială, 46, 243, 2014.

23. MCCARTHY E. Jerome. Basic marketing: a managerial approach. Homewood, IL: Richard D. Irwin, 1960.

24. BORDEN N.H. The concept of the marketing mix. J. Advertising Res., 4, (2), 2, 1964.

25. VAN WATERSCHOOT W., VAN DEN BULTE C. The 4P classification of the marketing mix revisited. J. Marketing, 56, (4), 83, 1992.

26. PEETERS W. Space marketing: a European perspective. Springer Science \& Business Media, 2001.

27. PORTER M.E. The Five Competitive Forces That Shape Strategy. Harvard Bus. Rev., 86, (1), 25, 2008.

28. PORTER M.E. America's green strategy. Business and the Environment: A Reader, 1996.

29. GULA A., GORYL W. Toward a More Environmentally Friendly Use of Biomass for Energy Purposes in Poland. Pol. J. Environ. Stud., 23, (4), 1377, 2014. 